\title{
Constraints Perceived by Camel Owners Related to Management and Marketing Practices
}

\author{
Kamlesh Kumar Dhawal $^{*}$, Devi Singh Rajput ${ }^{2}$, Maina Kumari ${ }^{3}$, \\ Neeraj Kumar Sharma ${ }^{2}$ and Pankaj Mishra ${ }^{1}$ \\ ${ }^{1}$ Animal Husbandry Department, Rajasthan (India) \\ ${ }^{2}$ Department of Veterinary and Animal Husbandry Extension Education, College of \\ Veterinary and Animal Science (RAJUVAS), Bikaner, Rajasthan (India) \\ ${ }^{3}$ Department of Veterinary and Animal Husbandry Extension Education, Apollo College of \\ Veterinary Medicine, Jaipur, Rajasthan (India) \\ *Corresponding author
}

A B S T R A C T

Keywords

Camel, Constraints,

Mechanization,

Organised Market,

Pastureland, Utility

Article Info

Accepted:

15 December 2020

Available Online:

10 January 2021
The present study was done to investigate the different constraints about camel management and marketing. A total of 120 camel owners' families were randomly selected from 8 purposively selected villages from 2 purposively selected districts i.e. Bikaner and Jaisalmer on the basis of camel population. The quantitative and qualitative data were collected through semi-structured interview schedule, discussion and observation. The investigation revealed that major constraints were decreasing utility of camel in farm operations and transportation due to mechanisation, lack of organised market for selling of camel and its product and insufficient grazing pasture. Decreasing price of camel, high cost of feed and fodder and high cost of veterinary treatment were the next serious constraint in camel management and marketing.

\section{Introduction}

Majority of the world's camel population is of dromedary type except small population of Bactrian camels in central Asia (Simenew et al., 2013). There are about 35 million of camel according to FAO in which 2.5 lakh are in India (Anonymous, 2019). Camel is one of the important components of the desert ecosystem from time immemorial and is also designated as the "Ship of the desert".
Humans depend on camel not just for meat, milk and hide but also as one of the most important mode of transport in the desert. Camels play an important socio-economic role within the pastoral and agricultural system in arid and semi-arid zones of Asia and Africa (Gwida et al., 2011). Camels contribute significantly to the livelihood of the pastoralist and agro-pastoralists living in the harsh environments (Tura et al., 2010). There are many communities and pastoralist 
groups are depending upon camels for their livelihood in diverse eco-zones throughout the world. Camel population is numerous in arid and sub-arid area of the world especially African countries (FAO, 2019). In India camel mainly residing at Thar desert across the Indo-Pak border in states Rajasthan, Gujrat, Haryana and Punjab and the number decreased during last two decades. The increasing human population pressure and declining per animal feed production precipitated an urgent need to develop previously marginal resources, such as the semi-arid and arid rangelands, and to optimize their utilization through appropriate livestock production systems among which camel production is one of the most suitable animals (Mehari et al., 2007). The major ethnic groups owning camels in India are the Raika, Rebari, Jat and Bishnoi (Rajput and Tripathi, 2005). Camel-based livestock system will generate employment and help to improve income of the local rural population (Patil, 2011). Together with the socio-economic importance of camel, lies on serving as a cheap source of power for drawing water from wells, ploughing, leveling of land, working mini mills for oil extraction, grinding grains, crushing sugarcane and pulling carts to transport goods as well as people. Camels are also engaged in the transport of salt, fuel wood, agricultural products and household goods. These facts tend to suggest that the camel can be of immense help to improve the livelihoods of those involved in its raising, provided they supplement their traditional management systems with modern husbandry practices and health care of their animals. Camels also provide milk and meat, not only in very arid regions but also in several urban areas in many countries (Ahmad et al., 2010). Camels have been reported to be diurnal or nocturnal animals and have the ability to utilize vegetation in the desert and semidesert that other animals usually find unpalatable (Ghaji and Adegwa 1986). These characteristics features of camel have made it possible to use marginal and desertification ecosystems and over the centuries, the camel has been symbolling of stability for the pastoralists in the arid zone of world (Tura et al., 2010; Berhanu et al., 2013). Camel population in Rajasthan is about 2.13 lakh which is highest in India but registered a sharp decline of 34.96 per cent in comparison with Census, 2012 (Anonymous, 2019). This decline in numbers because of camelid raising practices have been changing recently. Urbanization and mechanization, traditional cultures that rely on camels and are associated with nomadic, sedentary or partially sedentary lifestyles, are facing important changes with the decline of extensive camel husbandry (Gossner et al., 2016). The current changes in the camel rearing practices are modifying the traditional relationships between the camel and its environment (Faye et al., 2012). In a country like India, the decline of the camel is mainly due to the expansion of crop cultivation into arid lands. Prime culprits for this development are irrigation agriculture and the establishment of natural reserves (Rollefson, 2005). There is little known about camels' production potential and production systems compared to other domestic animals. Researchers and funding agencies have been very reluctant to act on camel research for improvement of their production. Moreover, in the study area there is very limited information related to camel husbandry and management systems. Hence, the present study was carried out so as to identify the major managemental and marketing constraints.

\section{Materials and Methods}

The present study was carried out in 8 purposively selected villages from 2 tehsils. Each tehsil was purposively selected from purposively selected 2 districts i.e. Bikaner and Jaisalmer based on camel population. 
Total 15 respondents were randomly selected from each village for the study. Thus, total sample size was 120. Data were collected through presented semi-structured interview schedule pertaining the question related to different constraints felt by camel owners in management or marketing. Besides these, qualitative and quantitative data were also collected through interaction and discussion with camel owners, key informants, milkman and other secondary sources by spending 30 days. Data thus generated were analysed by calculating, simple frequencies, percentage, mean and rank using SPSS tools along with descriptive analysis.

\section{Results and Discussion}

It can be inferred from Table that 'decreasing utility of camel due to mechanization in farm operations and transport system' was reported as very serious constraint by 95 per cent and cent per cent of camel owners of Bikaner and Jaisalmer district and assigned rank $1^{\text {st }}$ in pooled data with mean score of 2.98. Further, lack of organized camel market for selling camel and its products was $2^{\text {nd }}$ most constraint reported by 93.33 per cent and 98.33 per cent of respondents from Bikaner and Jaisalmer districts, respectively and mean score was 2.96 in pooled data.

Table.1 Different constraints perceived by camel owners

\begin{tabular}{|c|c|c|c|c|c|c|c|c|c|c|c|c|}
\hline \multirow[b]{2}{*}{ Sr. No. } & \multirow[t]{2}{*}{ Constraint } & \multicolumn{3}{|c|}{ Bikaner } & \multicolumn{3}{|c|}{ Jaisalmer } & \multicolumn{3}{|c|}{ Pooled } & \multirow{2}{*}{$\begin{array}{l}\text { Mean } \\
\text { Score }\end{array}$} & \multirow[t]{2}{*}{ Rank } \\
\hline & & $\begin{array}{c}\text { Very } \\
\text { serious }\end{array}$ & Serious & $\begin{array}{l}\text { Not so } \\
\text { serious }\end{array}$ & $\begin{array}{c}\text { Very } \\
\text { serious }\end{array}$ & Serious & $\begin{array}{l}\text { Not so } \\
\text { serious }\end{array}$ & $\begin{array}{l}\text { Very } \\
\text { serious }\end{array}$ & Serious & $\begin{array}{l}\text { Not so } \\
\text { serious }\end{array}$ & & \\
\hline 1. & $\begin{array}{l}\text { Decreasing } \\
\text { utility of camel } \\
\text { due to } \\
\text { mechanization }\end{array}$ & $57(95.00)$ & $3(5.00)$ & 0 & $60(100)$ & 0 & 0 & $\begin{array}{c}117 \\
(97.5)\end{array}$ & $3(2.50)$ & 0 & 2.98 & I \\
\hline 2. & $\begin{array}{l}\text { Poor economic } \\
\text { condition }\end{array}$ & $34(56.67)$ & $\begin{array}{c}17 \\
(28.33)\end{array}$ & $\begin{array}{c}9 \\
(15.00)\end{array}$ & $31(51.67)$ & $\begin{array}{c}24 \\
(40.00)\end{array}$ & $5(8.33)$ & $\begin{array}{c}65 \\
(54.17)\end{array}$ & $\begin{array}{c}41 \\
(34.17)\end{array}$ & $\begin{array}{c}14 \\
(11.67)\end{array}$ & 2.43 & IX \\
\hline 3. & $\begin{array}{l}\text { Insufficient } \\
\text { grazing pasture }\end{array}$ & $47(78.33)$ & $\begin{array}{c}13 \\
(21.67)\end{array}$ & 0 & $58(96.67)$ & $2(3.33)$ & 0 & $\begin{array}{c}105 \\
(87.50)\end{array}$ & $\begin{array}{c}15 \\
(12.50)\end{array}$ & 0 & 2.88 & III \\
\hline 4. & $\begin{array}{l}\text { Lack of } \\
\text { organized } \\
\text { market for } \\
\text { camel and milk }\end{array}$ & $56(93.33)$ & $4(6.67)$ & 0 & $59(98.33)$ & $1(1.67)$ & 0 & $\begin{array}{c}115 \\
(95.83)\end{array}$ & $5(4.17)$ & 0 & 2.96 & II \\
\hline 5. & $\begin{array}{l}\text { High } \\
\text { maintenance } \\
\text { cost of camel }\end{array}$ & $29(48.33)$ & $\begin{array}{c}31 \\
(51.17)\end{array}$ & 0 & $35(58.33)$ & $\begin{array}{c}25 \\
(41.67)\end{array}$ & 0 & $\begin{array}{c}64 \\
(53.33)\end{array}$ & $\begin{array}{c}56 \\
(46.67)\end{array}$ & 0 & 2.53 & VII \\
\hline 6. & $\begin{array}{l}\text { Decreasing } \\
\text { price of camel }\end{array}$ & $44(73.33)$ & $\begin{array}{c}16 \\
(26.67)\end{array}$ & 0 & $51(85.00)$ & $\begin{array}{c}9 \\
(15.00)\end{array}$ & 0 & $\begin{array}{c}95 \\
(79.17)\end{array}$ & $\begin{array}{c}25 \\
(20.83)\end{array}$ & 0 & 2.79 & IV \\
\hline 7. & $\begin{array}{l}\text { High cost of } \\
\text { veterinary } \\
\text { treatment }\end{array}$ & $34(56.67)$ & $\begin{array}{c}24 \\
(40.00)\end{array}$ & $2(3.33)$ & $40(66.67)$ & $\begin{array}{c}18 \\
(30.00)\end{array}$ & $2(3.33)$ & $\begin{array}{c}74 \\
(61.67)\end{array}$ & $\begin{array}{c}42 \\
(35.00)\end{array}$ & $4(3.33)$ & 2.58 & VI \\
\hline 8. & $\begin{array}{l}\text { High cost of } \\
\text { feed and fodder }\end{array}$ & 37 (61.67) & $\begin{array}{c}19 \\
(31.67)\end{array}$ & $4(6.67)$ & $39(65.00)$ & $\begin{array}{c}20 \\
(33.33)\end{array}$ & $1(1.67)$ & $\begin{array}{c}76 \\
(63.33)\end{array}$ & $\begin{array}{c}39 \\
(32.50)\end{array}$ & $5(4.17)$ & 2.59 & V \\
\hline 9. & $\begin{array}{l}\text { Poor } \\
\text { knowledge } \\
\text { about insurance } \\
\text { and other govt. } \\
\text { schemes }\end{array}$ & $27(45.00)$ & $\begin{array}{c}29 \\
(48.33)\end{array}$ & $4(6.67)$ & $35(58.33)$ & $\begin{array}{c}15 \\
(25.00)\end{array}$ & $\begin{array}{c}10 \\
(16.67)\end{array}$ & $\begin{array}{c}62 \\
(51.67)\end{array}$ & $\begin{array}{c}44 \\
(36.67)\end{array}$ & $\begin{array}{c}14 \\
(11.67)\end{array}$ & 2.40 & $\mathrm{X}$ \\
\hline 10. & $\begin{array}{l}\text { Lack of } \\
\text { government } \\
\text { initiative }\end{array}$ & $32(53.33)$ & $\begin{array}{c}23 \\
(38.33)\end{array}$ & $5(8.33)$ & $35(58.33)$ & $\begin{array}{c}22 \\
(36.67)\end{array}$ & $3(5.00)$ & $\begin{array}{c}67 \\
(55.83)\end{array}$ & $\begin{array}{c}45 \\
(37.50)\end{array}$ & $8(6.67)$ & 2.49 & VIII \\
\hline
\end{tabular}

(Figures in parentheses indicates percentage) 
Fig.1

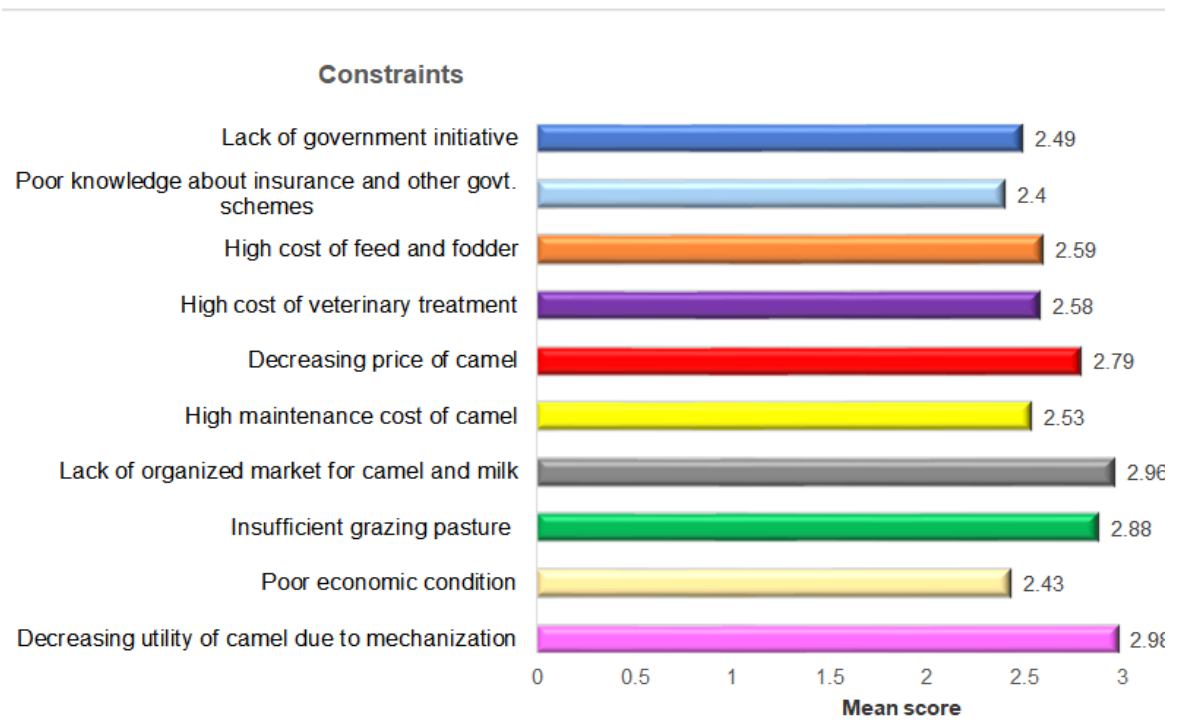

Table further revealed that insufficient grazing pasture for camel (78.33 and 96.67\%) and decreasing price of camel (73.33 and $85 \%)$ and high cost of feed and fodder $(61.67$ and $65.00 \%$ ) reported as next very serious constraints in Bikaner and Jaisalmer districts and ranked $3^{\text {rd }}, 4^{\text {th }}$ and $5^{\text {th }}$ with mean score of $2.88,2.79$ and 2.59, respectively. Other serious constraints were high cost of veterinary treatment (56.7 and $66.67 \%$ ), high maintenance cost (48.33 and 58.33\%) and lack of government initiative (53.33and $58.33 \%$ ) in Bikaner and Jaisalmer districts and ranked $6^{\text {th }}, 7^{\text {th }}$ and $8^{\text {th }}$ with mean score of $2.58,2.53$ and 2.49 , respectively. It is also reflected from pooled data that poor economic condition and poor knowledge of insurance and other government schemes were reported not so serious constraints with assigned lower rank of $9^{\text {th }}$ and $10^{\text {th }}$, respectively. Similar findings were observed by Abdisa et al., (2017) as they reported that camel diseases, poor overall knowledge, lack or insufficient market infrastructure and lack of information were major constraints in camel rearing in Southern Ethiopia.
There was mechanisation in both the districts as tractors were mostly used in farms operation as itself provide multipurpose work from ploughing to chaff cutting. Camel owners are compelled to adopt new mechanical tools which resulted in less utilization of camel in farm as it takes more time and management. Farmers are more tend towards the commercial agriculture activities and by products are used as fodder in animals. This led to shortening of grazing land day by day. In Bikaner, study areas were near to canal system which rapidly and drastically changed grazing land into the agricultural land due to which there was limited and insufficient grazing area available to camels. Camel and camel milk are not utilized as food due to law and some traditional issues. However, camel milk utilized for medicinal purpose but due to lack of awareness about medicinal properties of camel milk among common people and not being a regular part of daily meal private or government agencies less enthusiastic to establish organised camel marketing. 
The findings concluded that decrease utilization of camel due to mechanization of transport system and farm operations, low availability of grazing pasture, high cost of feed \& fodder and infectious diseases were the factors which demoralized the camel owners to continue the traditional camel farming occupation. There is urgent need to

Pay attention and develop a suitable strategy/ policy for increasing pastureland.

Search alternate means of camel utilization.

Rural youth might be encouraged to take up the camel husbandry.

Credit facilities and the subsidized schemes might be implemented to help the needy camel owners.

That would be an effective measure for consistent utilization of camel potential as well as existence of survival of this valuable species.

\section{References}

Abdisa, T., Wubishet, Z., Etsay, K. (2017). Study on Major Constraints of Camel Production, Management and Their Impacts in and Around Yabello District, Oromia Regional State, Southern Ethiopia. Dairy and Veterinary Science Journal, 3(1), 555-604.

Ahmad, S., Yaqoob, M., Hashmi, N., Zaman, A. and Tariq, M. (2010). Economic Importance of Camel: A Unique Alternative under Crisis. Pakistan Veterinary Journal, 30(4), 191-197.

Anonymous (2019). 20 $0^{\text {th }}$ Livestock Population. Department of Animal Husbandry and Dairy, Ministry of Agriculture. Govt. of India.

Berhanu, T.B., Merga, B., Relay and Endrias, Z. (2013). Camel brucellosis and management practices in Jigiiga and Babile districts, Eastern Ethiopia. Journal of Veterinary
Medicine and Animal Health.

FAO (2019). Rome, Italy. FAOSTAT.

Faye, B., Chaibou, M. and Vias, G. (2012). Integrated impact of climate change and socioeconomic development on the evolution of camel farming systems. British Journal of Environment and Climate Change, 2(3), 227-244.

Ghaji, A. and Adegwa, A.O. (1986). The significance of camel production in Nigeria. Nigerian Journal of Animal Science, 13, 29-35.

Gossner, C., Danielson, N., Gervelmeyer, A., Berthe, F., Faye, B. and Kaasik, A.K. (2016). Human-dromedary camel interactions and the risk of acquiring zoonotic Middle East respiratory syndrome coronavirus infection. Zoonoses and Public Health, 63(1), 1-9.

Gwida, M., El-Gohary, A., Melzer, F., Khan, I. and Rösler, U. (2011). Brucellosis in camels. Research in Veterinary Science, 92(3), 351-355.

Mehari, Y., Mekuriaw, Z. and Gebru, G. (2007). Potentials of camel production in Babile and Kebribeyahworedas of the Jijiga Zone, Somali Region, Ethiopia. Livestock Research for rural development, 19(4).

Patil, N.V. (2011). National Research Centre on Camel. Jorbeer, Bikaner 334001. Indian Council of Agricultural Research Vision 2030, Rajasthan, India.

Rollefson, I.K. (2005). Camels on rapid decline in Asia. League for Pastoral Peoples and endogenous livestock people, www.pastoralpeoples.org.

Simenew, K., Dejen, T., Tesfaye, S., Fekadu, R., Tesfu, T. and Fufa, D. (2013). Characterization of Camel Production System in Afar Pastoralists, North East Ethiopia. Asian Journal of Agricultural Sciences, 5(2), 16-24.

Tura, I., Kuria, G., Walaga, H.K. and Lesuper, J. (2010). Camel Breeding Management among the Somali, Sakuye, Gabbra and Rendille Pastoralists of Northern Kenya. Tropentag, Zurich, Switzerland. 


\section{How to cite this article:}

Kamlesh Kumar Dhawal, Devi Singh Rajput, Maina Kumari, Neeraj Kumar Sharma and Pankaj Mishra. 2021. Constraints Perceived by Camel Owners Related to Management and Marketing Practices. Int.J.Curr.Microbiol.App.Sci. 10(01): 2595-2600. doi: https://doi.org/10.20546/ijcmas.2021.1001.302 